Research paper

\title{
Exploring the potential of grass feedstock from marginal land in Ireland: Does marginal mean lower yield?
}

\author{
Peter Meehan, Brendan Burke, Deirdre Doyle, Susanne Barth, John Finnan* \\ Crops Research Department, Crops Environment and Land Use Programme, Teagasc, Oak Park, Ireland
}

\section{A R T I C L E I N F O}

\section{Keywords:}

Biomethane

Energy

Festulolium

Grass

Marginal land

\begin{abstract}
A B S T R A C T
The production of biomass feedstock from marginal land has attracted much attention as a means of avoiding conflict between the production of food and fuel. Yield potentials from marginal lands have generally not been quantified although it is generally assumed that lower biomass yields can be expected from marginal lands. A three year study was conducted in Ireland in order to determine if grass yields of perennial rhizomatous grasses (cocksfoot, tall fescue, reed canary grass, festulolium) for anaerobic digestion from three marginal land sites (very wet site, very dry site, site prone to flooding) could match yields from better soils. Randomised complete block designs were established on each site in 2012 with two varieties of each grass species as treatments. Three grass harvests were taken from each site in 2013 and in 2014. There was no significant difference between yields from the control site and those from the very dry site and the site prone to flooding. Biomass yields from the very wet site were $85 \%$ of those from the control site. Highest yields were obtained from festulolium which were significantly higher than yields from perennial ryegrass. An energy analysis showed that maximising the production of grass from low lying mineral marginal grassland in Ireland could provide enough energy to meet the energy requirements of both the private car fleet and the heavy goods vehicle fleet while avoiding conflict with food production which could be concentrated on conventional land.
\end{abstract}

\section{Introduction}

Energy produced from biomass could produce a substantial proportion of global primary energy needs by 2050 [1]. However, estimates for the contribution of biomass resources to global energy production have produced a wide range of results [2,3]. Major differences in estimates have been ascribed to different assumptions on land availability and yield levels [2]. The conversion of large areas of land to bioenergy production has raised concerns over the effect of such a change on the environment [4]. Furthermore, competition between bioenergy and food production for land and resources has led to a fuel vs. fuel debate $[5,6]$ and it is anticipated that such competition will increase as the 21st century unfolds [7].

The use of abandoned agricultural land for bioenergy production has been suggested as a means of potentially avoiding conflicts between the production of food and energy [8,9]. It has been suggested [10] that the use of marginal land for bioenergy production could offer significant environmental and economic benefit but only when perennial energy crops are employed and sustainable land management practises are used. Estimates of the area of marginal land available worldwide for bioenergy production range from 100 Mha [11] to 580 Mha [12]. Wide variation in the estimates of marginal land availability have been attributed to ambiguity in the definition and characterization of marginal land together with uncertainty in assessments of land availability [13]. Various concerns have been expressed over the large scale use of marginal land for the production of biomass. For example, it has been suggested that the use of marginal land for biomass production represents a sub-optimal land use allocation which is costly to society [14]. Additionally, it has been suggested that the cultivation of energy crops on marginal land may lead to losses in soil carbon and changes to biodiversity although such changes may be minimised by using biomass already growing in such areas [13,15].

Biogas obtained from grass silage has the potential to play an important role in reducing Ireland's dependency on imported fossil fuels. Previous studies have shown the impact of biogas obtained from grass silage could have on Ireland's energy supply [16,17]. As much as 1.7 million tonnes DM/ha of grass could be made available under current agricultural practice prior to increased demand from national production target commitments [16]. This could be increased to 12.2 million tonnes DM/ha even after national agricultural production target requirements are taken into consideration by increasing nitrogen $(\mathrm{N})$ inputs and increasing the grazed grass utilization rate of cattle [16]. A

\footnotetext{
* Corresponding author.

E-mail address: John.finnan@teagasc.ie (J. Finnan).
} 
study conducted in Ireland [18] found that $107 \mathrm{~m}^{3} \mathrm{CH}_{4} /$ tonne of biomass could be achieved from grass silage and that $1.1 \%$ of grassland (45,000 ha) could produce $6.6 \mathrm{PJ}$ of energy while $2.8 \%$ of grassland (111,000 ha) could produce enough grass silage to generate $16.07 \mathrm{PJ}$ of energy. These studies examined grass production from conventional agricultural grassland. In contrast, few studies have quantified the productivity of marginal land. This study, however, will examine the production of grass silage from less productive, under-utilised marginal land. Marginal land can be defined as synonymous with those areas beset by natural limitations imposed by soil, topography or climate [19]. According to [20], 56\% of the land area in Ireland can be classified as difficult or marginal, this area being divided into 0.81 million hectares (Mha) of lowland, mineral wet land, 1.14 Mha of hill or mountain land and 1.2 Mha of peat. For the purpose of grass production for anaerobic digestion, the only relevant category of marginal land is the 0.81 Mha of lowland, wet mineral soil. This category of marginal land is almost completely used for growing grass, thus the use of this grassland for biomethane production does not represent a change of use. The botanical composition of these grasslands consists of moderate to low quality swards [20] but reseeding can offer enhanced productivity [21]. Perennial ryegrass (Lolium perenne) is the dominant grass used for reseeding in Ireland [20,21] due to its high productivity although perennial rhizamatous grasses tend to be more tolerant of conditions found on marginal land [22,23] and it has been suggested that such grasses can be used to maximise biomass production from marginal land [24].

The objective of this study was to (1) quantify the productivity of perennial rhizomatous grasses on different marginal soils in Ireland and (2) quantify the potential contribution of grassland from marginal land to indigenous energy generation and greenhouse gas mitigation in Ireland.

\section{Material and methods}

Experiment were conducted on four separate sites over a three year period (2012-2014) to determine the effect of marginal site and species on grass yields for anaerobic digestion. The experimental design was a randomised complete block. Four perennial rhizomatous species were included in each trial (Dactylis glomerata (cocksfoot); Festuca arundinacea (tall fescue); Lolium $x$ Festuca (Festulolium); Phalaris arundinacea (Reed canary grass)) together with perennial ryegrass (Lolium perenne), the predominant grass species used in Ireland which was included as a control. Two varieties of each species were included in all trials (Table 1). The site name, location, altitude and description are presented in Table 2. Three of the sites were located near Carlow (control, dry site, flooding site) while the wet site was located near Johnstown Castle, Co Wexford, approximately $60 \mathrm{~km}$ distant from Carlow. Meteorological parameters were recorded at synoptic weather stations located at each site.

The experiments in the control site, dry site and flooding site were all sown on May 24th, 2012 whereas the experiment in the wet site was sown on May 20th, 2012. All locations were sown in good conditions using a Wintersteiger seed drill (Wintersteiger, Dimmelstrasse 9, Ried/ L, Austria) using conventional (plough-based) cultivation practices, and rolled immediately afterwards. The plots were sown at a seeding rate of

Table 1

Grass species used in the experiments.

\begin{tabular}{llllll}
\hline & $\begin{array}{l}\text { Cocksfoot } \\
\text { (Dactylis } \\
\text { glomerata) }\end{array}$ & $\begin{array}{l}\text { Tall Fescue } \\
\text { (Festuca } \\
\text { arundinacea) }\end{array}$ & $\begin{array}{l}\text { Perennial } \\
\text { ryegrass } \\
\text { (Lolium } \\
\text { perenne) }\end{array}$ & $\begin{array}{l}\text { Festulolium } \\
\text { (Lolium x } \\
\text { Festuca) }\end{array}$ & $\begin{array}{l}\text { Reed Canary } \\
\text { Grass } \\
\text { (Phalaris } \\
\text { arundinacea) }\end{array}$ \\
\hline Variety & $\begin{array}{l}\text { Ambassador } \\
\text { Donata }\end{array}$ & $\begin{array}{l}\text { Jordane } \\
\text { Emeraude }\end{array}$ & $\begin{array}{l}\text { Carraig } \\
\text { Cancan }\end{array}$ & $\begin{array}{l}\text { Felina } \\
\text { Hykor }\end{array}$ & $\begin{array}{l}\text { Bamse } \\
\text { Cheifton }\end{array}$ \\
\hline
\end{tabular}

$30 \mathrm{~kg} / \mathrm{ha}$. Inclement weather conditions over the summer of 2012 led to flooding at the flooding site which was flooded for a six week period soon after emergence. Consequently, the site was re-sown on September 7th, 2012. All experiments were left to establish during the 2012 growing season, growth was mown and removed at the end of this growing season.

The trial plots were managed to obtain three cuts of silage in each year in order to maximise the quantity of grass produced as a feedstock for anaerobic digestion. To maximise productivity, the highest rates of nitrogen permitted under the nitrates directive were applied prior to each cut [25]. Nitrogen fertilizer was applied approximately six weeks before the intended date of the first cut and then immediately after the first and second cuts of grass were removed. Soil testing was carried out to determine soil nutrient status and phosphorus, potassium and lime were applied to each site as necessary in order to ensure that the supply of all macronutrients was non-limiting. The rate of fertilizer applied is given in Table 3. Lime was applied to the control site as well as the wet site prior to the first cut at a rate of 270 and $370 \mathrm{~kg} / \mathrm{ha}$ respectively.

\subsection{Yield and dry matter determination}

The grass crop was harvested on three occasions each year. The first cut was harvested between 4th and 7th of June in 2013, and 27th and 29th of June in 2014; the second cut harvest was carried out between the 29th and 31st of July in 2013 and 2014. The third cut was harvested between the 24th and 23rd of September in 2013 and 17th and 18th of September in 2014. The grass plots were harvested using a Haldrup plot harvester (J. Haldrup, Løgstør, Denmark). A sample of fresh material was collected once the plot weight was recorded and used to determine the dry matter (DM) content of the grasses.

The percentage DM of the crop was determined by weighing the fresh sample collected from the field, oven drying it at $65^{\circ} \mathrm{C}$ until constant weight was achieved. This DM recorded for each plot was then used to calculate the yield of the each plot on a per hectare basis (t DM/ ha).

\subsection{Statistical analysis}

The data was analysed using a GLIMMIX analysis with repeated measures in Ref. [26] to determine statistical differences between the varieties of grass and the trial sites. Year, site, treatment and replicate were the fixed factors in the analysis whereas year was treated as a random factor. Pairwise differences in treatments were evaluated using Tukey's test.

\subsection{Energy analysis and Life Cycle Assessment}

\subsubsection{Scope}

The analysis was based on a farm based anaerobic digester as described by Ref. [27] who assumed grass yields similar to those measured in this study.

The scope of this analysis extended from the production of grass, the production of biomethane in an anaerobic digestor through to the final use of the biomethane in vehicles. For the energy analysis, all direct energy inputs used in the production of grass and, subsequently, biomethane were included in the analysis. Indirect energy needed in the production of seed, lime, chemical fertilizer and diesel was also included in the analysis although energy consumed in the manufacture of equipment and infrastructure was not included in line with the methodologies proscribed by the European Union for the calculation of the greenhouse gas impact of biofuels, bioliquids and their fossil fuel comparators [28]. The functional unit was 1 ha/annum.

\subsubsection{Harvesting and yields}

Three harvests were assumed to be taken each year in order to maximise biomass production from the grass swards (early June, late 
Table 2

Four experimental sites used in the experiments. Soil indices [25].

\begin{tabular}{|c|c|c|c|c|c|c|c|c|c|}
\hline Site Classification & Site & Site Description & History & Lat. & Long. & Altitude (m) & $\mathrm{K}$ & $\mathrm{P}$ & $\mathrm{pH}$ \\
\hline Control Site & $\begin{array}{l}\text { Farrell's Field } \\
\text { (FF) }\end{array}$ & $\begin{array}{l}\text { Highly productive tillage soil with good clay content and } \\
\text { water retention ( }>45 \% \text { clay) }\end{array}$ & $\begin{array}{l}\text { Long term cereal } \\
\text { cultivation }\end{array}$ & 52.85 & -6.94 & 42 & 2 & 4 & 6.71 \\
\hline Dry site & $\begin{array}{l}\text { Far Avenue Meadow } \\
\text { (FAM) }\end{array}$ & $\begin{array}{l}\text { Shallow soil with high content of gravel and sand with poor } \\
\text { water retention characteristics }\end{array}$ & $\begin{array}{l}\text { Long term cereal } \\
\text { cultivation }\end{array}$ & 52.85 & -6.90 & 63 & 3 & 4 & 7.35 \\
\hline Flooding site & $\begin{array}{l}\text { Bog Field } \\
\text { (BF) }\end{array}$ & $\begin{array}{l}\text { Alluvial soil formed from river deposits and prone to flooding } \\
\text { when the river water level is high }\end{array}$ & Summer grazing & 52.86 & -6.94 & 15 & 1 & 2 & 7.92 \\
\hline Wet site & $\begin{array}{l}\text { Johnstown Castle } \\
\text { (JC) }\end{array}$ & Poorly drained soil with many springs and a high water table & Summer grazing & 52.29 & -6.53 & 71 & 2 & 1 & 6.08 \\
\hline
\end{tabular}

Table 3

Fertilization (kg/ha) applied to each site during 2013 and 2014.

\begin{tabular}{|c|c|c|c|c|c|c|c|c|c|}
\hline \multirow[t]{3}{*}{ Site } & \multicolumn{3}{|l|}{$\mathrm{N}$} & \multicolumn{3}{|l|}{$\mathrm{K}$} & \multicolumn{3}{|l|}{$\mathrm{P}$} \\
\hline & \multicolumn{9}{|l|}{ Cut } \\
\hline & $1 \mathrm{st}$ & 2nd & 3rd & $1 \mathrm{st}$ & 2nd & $3 \mathrm{rd}$ & 1st & 2nd & 3rd \\
\hline FAM & 125 & 100 & 100 & 120 & 35 & 35 & 0 & 0 & 0 \\
\hline $\mathrm{FF}$ & 125 & 100 & 100 & 150 & 50 & 50 & 0 & 0 & 0 \\
\hline $\mathrm{BF}$ & 125 & 100 & 100 & 175 & 70 & 70 & 30 & 10 & 10 \\
\hline JC & 125 & 100 & 100 & 150 & 50 & 50 & 40 & 10 & 10 \\
\hline
\end{tabular}

July, late September). The quantity of silage harvested annually was assumed to be the average Festulolium yields from the flooding site and the wet site used in this study (13.2 tonnes DM/ha/annum).

Prior to reseeding, after a growing cycle of eight growing seasons, the grass crop was sprayed off after the second cut of silage. Thus, silage yields from the 8 th growing season were reduced by $27 \%$, the proportion of total yield from the third harvest. Thus, the average yield over eight growing seasons was 12.8 tonnes DM/ha. The biomethane potential of the grasses examined in this study was determined based on a number of assumptions attained from literature [27,29,30]. Differences in biomass yield per hectare, grass species and the growth stage at which the grass is harvested all affect biomethane yields per hectare $[29,31,32]$. The effect of grass species on methane yields has been studied and several studies have concluded that the effect is secondary compared to other factors such as maturity $[29,31]$ although some studies have reported differences in methane yields between grass species particularly for species with low digestibility such as reed canary grass $[30,32]$. A study carried out by Wall, Kiely and Murphy [18], obtained a potential biomethane yield of $400 \mathrm{l} \mathrm{CH}_{4} \mathrm{~kg}^{-1}$ volatile solids (VS), from mono-digestion of ensiled grass with a dry solid content of $292.7 \mathrm{~g} \mathrm{~kg}^{-1}$, harvested at an early maturity stage under Irish conditions. For the purpose of this study, the VS content of the ensiled grass is assumed to be $91.7 \%$ of the DS weight [18,27]. Using this value, the total VS was determined from the grass DS yields recorded earlier in the study. Based on a value of $\mathrm{CH}_{4}$ yield of $4001 \mathrm{CH}_{4}$ $\mathrm{kg}^{-1} \mathrm{VS}$ [18], the biomethane potential per hectare of grass grown on marginal land was determined. A net calorific value of $35.9 \mathrm{MJ} \mathrm{m}^{-3}$ [18] was used to calculate gross energy production. Net energy was calculated by subtracting energy utilization during grass and biogas production, grass upgrading and transport from gross energy production.

Our study just considers one feedstock for anaerobic digestion (grass) but, in practise, manures and slurries could be co-mixed with the grass. However, biomethane yields from animal wastes are low [18].

\subsubsection{Reseeding}

It was assumed that grass swards were reseeded every eight years after the preceding sward was sprayed off prior to ploughing and reseeding. Reseeding was assumed to take place during the autumn using a seeding rate of $30 \mathrm{~kg} / \mathrm{ha}$ after the preceding crop had been sprayed off after the second harvest. Diesel used for spraying, ploughing, harrowing, sowing and rolling were obtained from Ref. [33]. The indirect energy associated with seed production $(12 \mathrm{MJ} / \mathrm{kg}$ seed) was taken from Ref. [34] while the indirect energy associated with the production of herbicide ( $40 \mathrm{MJ} / \mathrm{kg}$ ) was taken from Ref. [33].

\subsubsection{Fertilization}

It was assumed that all of the digestate produced by the anaerobic digestor (114 tonnes/ha; [27]) would be returned to the land from which the silage was harvested and that the nutrient content of the digestate would be sufficient to meet all of the phosphorus and potassium requirements and most of the nitrogen requirements of the grassland. A deficit of $85 \mathrm{~kg} \mathrm{~N} / \mathrm{ha}$ was met by spreading additional chemical fertilizer (calcium ammonium nitrate). It was assumed that 5 tonnes of lime would be spread every three years. The diesel consumption from loading lime or fertilizer was taken from Ref. [33] while it was assumed that the diesel consumed by a stationary tractor operating a vacuum pump when sucking digestate into a slurry tanker was $0.1 \mathrm{~L} /$ tonne. It was assumed that digestate, fertilizer and lime had to be transported an average distance of $2.5 \mathrm{~km}$ from the digestor before spreading (total round trip distance of $5 \mathrm{~km}$ ) and that the tractors involved travelled at an average speed of $20 \mathrm{~km} / \mathrm{h}$ with a fuel consumption of $20 \mathrm{~L} /$ hour. Diesel consumed during the spreading of digestate and fertilizer in the field was taken from Ref. [33] while it was assumed that diesel consumption during lime spreading was identical to diesel consumption during digestate application. The indirect energy associated with the production of lime (30 MJ/tonne) and nitrogenous fertilizer (50 MJ/kg) were taken from Ref. [33].

Indirect emissions of greenhouse gases (GHG) during the manufacture of $\mathrm{N}$ fertilizer were taken from Ref. [35] while emissions of $\mathrm{N}_{2} \mathrm{O}$ after application of digestate and $\mathrm{N}$ fertilizer were taken from Ref. [36]. Indirect emissions of GHG during lime manufacture and direct emissions of GHG after lime application were taken from Ref. [37].

\subsubsection{Silage harvesting and loading}

For the harvest of grass silage, a total diesel requirement of $1.6 \mathrm{~L}$ per fresh tonne was assumed which includes mowing, harvesting, transport and ensilage [38]. Loading silage into the digestor was assumed to consume $0.3 \mathrm{~L}$ diesel per fresh tonne of silage [33].

\subsubsection{Biogas production, biomethane upgrading and distribution}

A continually stirred tank reactor operating at 10\% DS was assumed [27]. The energy required for digester heating (17.1 GJ/ha/annum; [27]) was assumed to come from the combustion of a proportion of the biomethane generated from the anaerobic digestor while the energy required for macerating, mixing and pumping (4.87 GJ/ha/annum; [27]) was assumed to be provided by electricity from the grid. The energy required for biogas upgrading to biomethane was assumed to come from electricity from the grid. The electricity required for both scrubbing and compression was assumed to by $0.35 \mathrm{kWh} / \mathrm{m} 3$ [27]. Fugitive emissions from the anaerobic digestion plant were assumed to be equivalent to the loss of $1.8 \%$ of the biomethane produced [38]. It was assumed that the filling stations were located on the local distribution network and that the energy needed for natural gas local 
distribution is zero [29].

\subsubsection{GHG emissions}

Greenhouse gas emissions arising from the use of diesel fuel were calculated on the basis that the GHG emissions of diesel were $3.144 \mathrm{~kg}$ $\mathrm{CO}_{2}$ eq per litre diesel [40]. GHG emissions arising from fugitive emissions were calculated by converting the volume of fugitive biomethane emissions to a weight $\left(0.707 \mathrm{~kg} / \mathrm{m}^{3}\right)$ and using a global warming potential of 25 for methane [37]. GHG emissions from the use of indirect energy inputs (nitrogen fertilizer, lime, herbicide) were calculated using GHG intensity factors obtained from Styles and Jones [35]. GHG emissions from the production of grass seed were assumed to arise entirely from the use of diesel during grass seed production. The GHG intensity of electricity from the national grid (126.8 tonnes $\mathrm{CO}_{2}$ eq/TJ; SEAI, [41]) was used to convert electricity usage in the anaerobic digestor and electricity usage during biomethane upgrading to equivalent GHG emissions. Gross GHG mitigation was calculated by summing the GHG emissions of the vehicles [42] which could be powered from the biomethane production from 1 ha. The average fuel consumption of cars in Ireland in 2013 was $1.72 \mathrm{MJ} / \mathrm{km}$ and the combined average mileage was $18,000 \mathrm{~km} /$ annum giving an annual average vehicle consumption of $31 \mathrm{GJ} /$ annum [42]. Net GHG emissions were calculated by subtracting GHG emissions during the production of grass and biomethane from gross GHG mitigation.

\subsubsection{National upscaling and scenario analysis}

The potential biogas and net energy yield achieved from grass grown on the marginal land in Ireland was estimated using values presented by Ref. [20], who classified $11.8 \%$ of Irish farm land (810,000ha) as "low mineral wet or difficult" marginal land. Figures for net energy per hectare and net GHG mitigation per hectare were converted to maximum national potential savings assuming that all of this marginal land ( $810,000 \mathrm{ha})$ is used for biomethane production.

Given that grass produced for biomethane production on marginal land will take place on wet and difficult soils, it was assumed that wet summers would restrict grass production due to problems with access and trafficability. Consequently, calculations were carried out for a second scenario in which it was assumed that all marginal land was used for biomethane production but that that grass energy output would reduce to $40 \%$ of its potential value every third year either due to reductions in the quantity of grass harvested or in the quality of grass harvested for use as a feedstock for biomethane production. Average yield per annum in this scenario was 11.1 tonnes DM/ha. In this alternative scenario, the energy and GHG costs associated with harvesting, digester loading and digestate disposal were assumed to reduce in proportion to the quantity of grass silage harvested and the quantity of digestate produced. Similarly, the energy and GHG costs associated with fugitive emissions and biomethane production also reduced in proportion to the quantity of biomethane produced. In this scenario, it is envisaged that the costs associated with sowing would increase due to the fact that some newly sown areas would be subject to flooding and need to be resown.

Scenario 1: Three grass harvests per year can be harvested exploiting full yield potential from marginal grasslands

Scenario 2: Grass yields reduce by $40 \%$ every third year due to problems with access and traffic ability.

\section{Results}

\subsection{Meteorological parameters}

Meteorological parameters for both sites and both years from March to September are presented in Table 4. Air and soil temperatures were higher during the 2014 growing season compared to the 2013 growing season. Rainfall was greater during the 2014 growing season although
Table 4

Meteorological Variables from synoptic meteorological stations at Oak Park, Carlow (control site, dry site and flooding site) and Johnstown Castle, Wexford (wet site) during 2013-2014 (March to September).

\begin{tabular}{llllll}
\hline Year & Site & $\begin{array}{l}\text { Air Temperature } \\
\text { (average) } \\
\text { (degrees C) }\end{array}$ & $\begin{array}{l}\text { Rainfall } \\
\text { (total) } \\
(\mathrm{mm})\end{array}$ & $\begin{array}{l}\text { Solar } \\
\text { Radiation } \\
\left(\mathrm{MJ} / \mathrm{m}^{2} /\right. \\
\text { day) }\end{array}$ & $\begin{array}{l}\text { Soil Temp } \\
\text { @ } 5 \mathrm{cms} \\
\text { (degrees C) }\end{array}$ \\
\hline 2013 & Oak Park & 11.7 & 317.4 & 13.6 & 13.9 \\
2013 & $\begin{array}{l}\text { Johnstown } \\
\text { Castle }\end{array}$ & 11.7 & 336.2 & 15.4 & 13.9 \\
2014 & $\begin{array}{l}\text { Oak Park } \\
\text { Johnstown }\end{array}$ & 12.7 & 423 & 13.8 & 14.9 \\
& 12.5 & 441 & 15.0 & 15.1 \\
\hline
\end{tabular}

radiation levels were similar between both growing seasons. Air and soil temperatures were similar between the Carlow and Wexford sites in both years of the study although rainfall levels and levels of solar radiation were higher at the Wexford site in both years.

\subsection{Biomass yield}

\subsubsection{Biomass yield - main effects of species, site and year}

Species had a significant effect on biomass yield $(\mathrm{P}<0.0001)$ (Table 5). In a pairwise comparsion, Festulolium yielded significantly more biomass $(\mathrm{P}<0.05)$ compared to all other species while Festuca yielded significantly more biomass $(\mathrm{P}<0.05)$ compared to Dactylis but also to Lolium, which was the lowest yielding grass species. The effect of site on biomass yield was statistically significant $(\mathrm{P}<0.0001)$, highest yields were obtained from the control site and lowest yields from the wet site. There was no significant difference between yields from the control site, the dry site and the flooding site but biomass yields from the wet site were significantly lower $(\mathrm{P}<0.05)$ than the yields from the other three sites. Biomass yields from the wet site were 15\% lower than that from the control site. Year had a significant effect on biomass yields $(P<0.0001)$ which were significantly greater in 2014 compared to 2013.

\subsubsection{Interactions between species, site and year}

The highest yields were obtained from the first harvest, yields

Table 5

Grass yields from treatment, site and year expressed as tonnes DS/ha. Means followed by the same letter are not statistically significant.

\begin{tabular}{ll}
\hline & DS yield (tonnes/ha) \\
\hline Species & \\
Festulolium & $13.6 \mathrm{~A}$ \\
Festuca & $12.8 \mathrm{~B}$ \\
Phalaris & $12.5 \mathrm{BCE}$ \\
Dactylis & $12.3 \mathrm{C}$ \\
Lolium & $12.1 \mathrm{C}$ \\
Site & \\
Control & $13.3 \mathrm{~A}$ \\
Dry site & $13.2 \mathrm{~A}$ \\
Flooding site & $12.8 \mathrm{~A}$ \\
Wet site & $11.3 \mathrm{~B}$ \\
Year & \\
2013 & $10.8 \mathrm{~B}$ \\
2014 & $14.5 \mathrm{~A}$ \\
Statistics & \\
Species & $<0.0001$ \\
Site & $<0.0001$ \\
Year & $<0.0001$ \\
Year*site & $<0.0001$ \\
Year*treatment & $<0.01$ \\
Site*treatment & $<0.05$ \\
Year*site*treatment & $<0.05$ \\
\hline
\end{tabular}




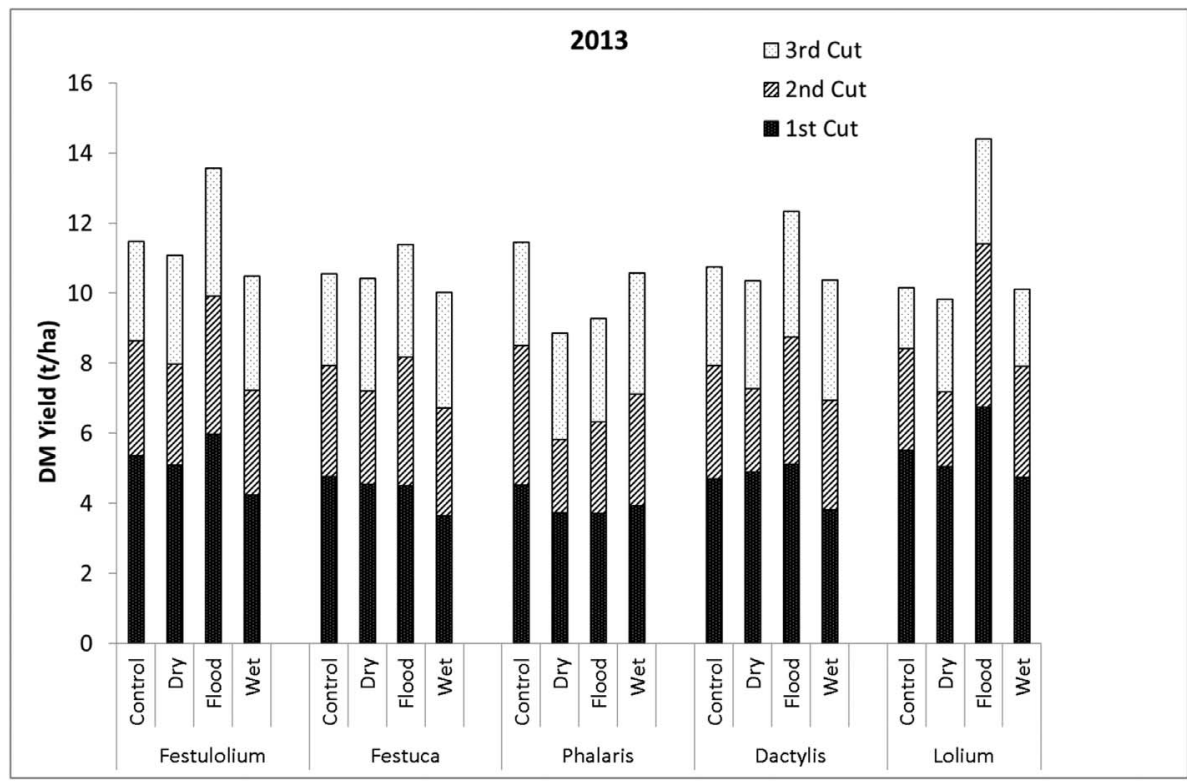

Fig. 1. Grass dry matter yields from the first, second and third harvests 2013-2014.

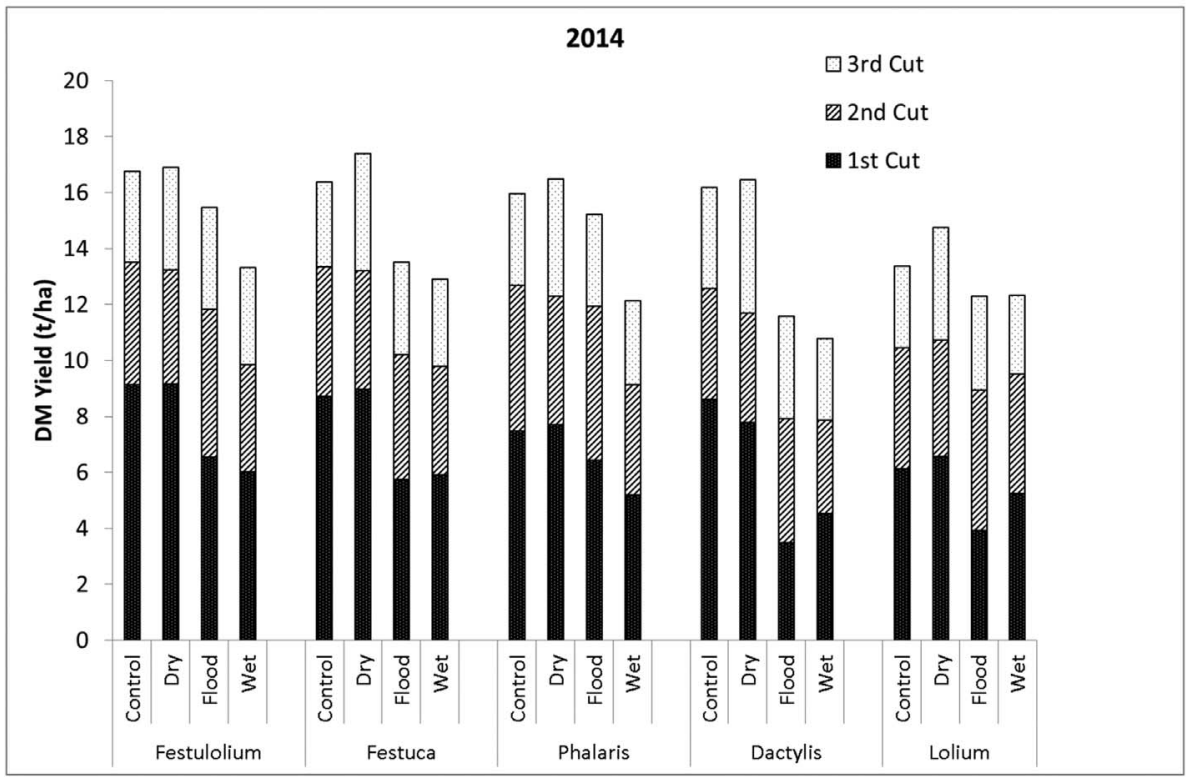

generally decreased from the first harvest to the third harvest in both years (Fig. 1). There was a significant interaction between year and site $(\mathrm{P}<0.0001)$ as all grass species with the exception of Phalaris produced their highest yields on the flooding site in 2013 whereas the highest yields were recorded from the control and dry sites in 2014 . Highest yields were obtained from Festulolium in both years (11.6 tonnes DM/ha in 2013; 15.6 tonnes DM/ha in 2014) although the relative yields of the other grass species changed between both years and there was a significant interaction between year and treatment $(\mathrm{P}<0.01)$. There was a significant interaction between site and treatment $(\mathrm{P}<0.05)$ as the performance of individual grass species varied depending on the environment in which they grew. This was particularly evident in 2014 when, for example, Dactylis yielded poorly in the flooding and wet sites compared to the other sites whereas there was less difference in the yields of Lolium and Festulolium between sites. There was also a significant interaction between site, year and treatment $(\mathrm{P}<0.05)$.

\subsection{Energy production}

\subsubsection{Scenario 1}

Energy inputs into the production of biomethane are shown in Table 6. Indirect energy costs associated with agriculture, loading silage and digestate disposal exceeded the direct energy cost from agriculture operations. The primary component of indirect energy costs was the manufacture of nitrogenous fertilizer which represented $73 \%$ of indirect energy cost. Direct energy costs associated with agricultural operations were dominated by the harvesting and transport of silage (79\% of direct energy costs). The direct energy cost of agricultural operations was only marginally greater than the direct energy costs associated with the loading, transport and spreading of digestate reflecting the substantial quantity (114 tonnes) of digestate which needed to be transported and spread. The production of biogas in anaerobic digesters followed by biogas upgrading to biomethane accounted for $66 \%$ of all energy costs. The largest energy cost associated with the production of biogas and biomethane was parasitic heat demand in which biomethane was burnt to generate heat. Heating the digester consumed $39 \%$ of the total energy cost associated with grass 
Table 6

Energy budget for scenario 1 (all grass available for anaerobic digestion) and scenario 2 (restricted grass availability).

\begin{tabular}{|c|c|c|}
\hline \multirow[t]{2}{*}{ Energy Cost } & \multirow{2}{*}{$\frac{\text { Scenario } 1}{\text { (MJ/ha/annum) }}$} & \multirow{2}{*}{$\begin{array}{l}\text { Scenario } 2 \\
\text { (MJ/ha/annum) }\end{array}$} \\
\hline & & \\
\hline \multicolumn{3}{|l|}{ Direct Energy Cost - Agriculture } \\
\hline Sowing & 158.0 & 236.9 \\
\hline Fertilizer loading & 3.6 & 3.6 \\
\hline Fertilizer transport & 538.5 & 538.5 \\
\hline Fertilizer spreading & 215.4 & 215.4 \\
\hline Lime loading & 14.4 & 14.4 \\
\hline Lime transport & 44.9 & 44.9 \\
\hline Lime spreading & 14.4 & 14.4 \\
\hline Harvesting and transport & 3676.2 & 3187.9 \\
\hline Total Direct Energy Cost (Agriculture) & 4665.2 & 4255.9 \\
\hline \multicolumn{3}{|l|}{ Indirect Energy Cost - Agriculture } \\
\hline Nitrogen fertilizer & 4250 & 4250 \\
\hline Lime & 48 & 48 \\
\hline Roundup & 86.4 & 86.4 \\
\hline Grass seed & 45 & 45 \\
\hline Diesel & 1381.2 & 1227.2 \\
\hline Total Indirect Energy Cost (Agriculture) & 5810.7 & 5656.6 \\
\hline \multicolumn{3}{|l|}{ Digestate Handling \& Spreading } \\
\hline Loading of digestate & 409.3 & 355.1 \\
\hline Transport of digestate & 2925.9 & 2534.5 \\
\hline Spreading of digestate & 1227.8 & 1066.2 \\
\hline Total Digestate Handling \& Spreading & 4562.9 & 3955.8 \\
\hline \multicolumn{3}{|l|}{ Biogas and Biomethane Generation } \\
\hline Loading of silage into digester & 689.3 & 599.5 \\
\hline Parasitic Heat Demand of Digester & 17100 & 17100 \\
\hline Energy in biogas production & 4870 & 4870 \\
\hline Biomethane production & 3276 & 2856 \\
\hline Fugitive emissions & 3024 & 2636 \\
\hline Total Biogas and Biomethane Generation & 28959.3 & 28061.5 \\
\hline Total Energy Cost & 43998.0 & 41929.9 \\
\hline \multicolumn{3}{|l|}{ Energy Produced } \\
\hline $4680 \mathrm{~m}^{3} \mathrm{CH}_{4} / \mathrm{ha}$ & 168012 & 146472 \\
\hline Net Energy Production & 124014 & 104542.1 \\
\hline \multirow[t]{2}{*}{ Marginal Land Energy Production } & 100.5 PJ & 84.7 \\
\hline & & PJ \\
\hline
\end{tabular}

production, biogas and biomethane production and digestate disposal. The total energy cost of biomethane production ( $44 \mathrm{GJ} / \mathrm{ha}$ ) represented $26 \%$ of gross energy production ( $168 \mathrm{GJ} / \mathrm{ha}$ ) expressed on a per hectare basis. A total of $101 \mathrm{PJ}$ of energy would be produced if all of the $11.8 \%$ of Irish land classified as lowland, mineral and wet is used for biomethane production.

\subsubsection{Scenario 2}

Total energy costs associated with scenario 2 ( $42 \mathrm{GJ} / \mathrm{ha}$ ) were lower (by approximately 5\%) compared to those of scenario 1 reflecting, primarily, lower diesel consumption in grass production, silage loading and digestate handling. The energy associated with biogas upgrading to biomethane was also reduced due to lower gas production as were the corresponding fugitive emissions. The total energy cost of biomethane in this scenario represented $29 \%$ of gross energy production (146 GJ/ ha). Total net energy production in this scenario amounts to $85 \mathrm{PJ}$ if all of the $11.8 \%$ of land classified as lowland, mineral and wet is used for biomethane production.

\subsection{Greenhouse house gas abatement}

\subsubsection{Scenario 1}

Direct emissions from agricultural operations were dominated by gaseous emissions of $\mathrm{N}_{2} \mathrm{O}$ from the application of digestate and nitrogenous fertilizer and of $\mathrm{CO}_{2}$ from the application of lime (Table 7). In comparison, emissions from diesel combustion associated with sowing, fertilization, harvesting and transport were comparatively small.
Table 7

Life Cycle Assessment for Scenario 1 (all grass available for anaerobic digestion) and Scenario 2 (restricted grass availability).

\begin{tabular}{|c|c|c|}
\hline \multirow[t]{2}{*}{ GHG emissions } & Scenario 1 & Scenario 2 \\
\hline & $\begin{array}{l}\mathrm{kg} \mathrm{CO} \\
\text { annum }\end{array}$ & $\begin{array}{l}\mathrm{kg} \mathrm{CO} \mathrm{CO}_{2} \mathrm{eq} / \mathrm{ha} / \\
\text { annum }\end{array}$ \\
\hline \multicolumn{3}{|l|}{ Direct GHG emissions - Agriculture } \\
\hline Sowing & 13.8 & 20.8 \\
\hline Fertilizer loading & 0.3 & 0.3 \\
\hline Fertilizer transport & 47.2 & 47.2 \\
\hline Fertilizer spreading & 18.9 & 18.9 \\
\hline Lime loading & 1.3 & 1.3 \\
\hline Lime transport & 3.9 & 3.9 \\
\hline Lime spreading & 1.3 & 1.3 \\
\hline Harvesting and transport & 321.9 & 279.2 \\
\hline $\mathrm{N}_{2} \mathrm{O}$ Emissions & 1522.8 & 1522.8 \\
\hline Lime Emissions & 733.0 & 733.0 \\
\hline Total Direct GHG emissions (Agriculture) & 2664.4 & 2628.5 \\
\hline \multicolumn{3}{|l|}{ Indirect GHG Emissions - Agriculture } \\
\hline Nitrogen fertilizer & 733.6 & 733.6 \\
\hline Lime & 1249.5 & 1249.5 \\
\hline Roundup & 13.6 & 13.6 \\
\hline Grass seed & 141.5 & 141.5 \\
\hline Total Indirect GHG Emissions (Agriculture) & 2138.1 & 2138.1 \\
\hline \multicolumn{3}{|c|}{ GHG Emissions Digestate - Handling \& Spreading } \\
\hline Loading of digestate & 35.8 & 31.1 \\
\hline Transport of digestate & 256.2 & 222.0 \\
\hline Spreading of digestate & 107.5 & 93.3 \\
\hline $\begin{array}{l}\text { Total GHG Emissions Digestate - } \\
\text { Handling \& Spreading }\end{array}$ & 399.6 & 346.4 \\
\hline \multicolumn{3}{|c|}{ GHG Emissions - Biogas and Biomethane Generation } \\
\hline Loading of silage into digester & 60.36 & 52.5 \\
\hline Parasitic Heat Demand of Digester & 1200.6 & 1200.6 \\
\hline Energy in biogas production & 617.516 & 617.5 \\
\hline Biomethane production & 415.4 & 362.1 \\
\hline Fugitive emissions & 1510 & 1313.8 \\
\hline $\begin{array}{l}\text { Total GHG Emissions - Biogas and } \\
\text { Biomethane Generation }\end{array}$ & 3803.9 & 3546.5 \\
\hline Total GHG Emissions & 9006.0 & 8659.6 \\
\hline \multicolumn{3}{|l|}{ Gross GHG Abatement } \\
\hline $4680 \mathrm{~m}^{3} \mathrm{CH}_{4} / \mathrm{ha}$ & 11805 & 10280 \\
\hline Net GHG Abatement & 2799.0 & 1620.4 \\
\hline $\begin{array}{l}\text { Marginal Land Net GHG Abatement (MT } \\
\quad \mathrm{CO}_{2} \text { eq) }\end{array}$ & 2.27 & 1.31 \\
\hline
\end{tabular}

Indirect agricultural emissions were dominated by emissions from the production of nitrogenous fertilizer and lime although emissions from lime production exceeded those from the production of nitrogen fertilizer as the use of fertilizer was substantially reduced as a result of the availability of digestate as a fertilizer. GHG emissions associated with digestate loading, transport and spreading were small compared to both direct and indirect emissions from agriculture operations. Emissions from the anaerobic digestor associated with the production of biogas and biomethane exceeded the emissions associated with direct agricultural operations as well as the indirect emissions from agricultural operations and were dominated by emissions associated with the use of biomethane for parasitic heat demand as well as with fugitive emissions from the plant. GHG emissions during the production of grass and its subsequent conversion to biomethane (9006 $\left.\mathrm{kg} \mathrm{CO}_{2} \mathrm{eq} / \mathrm{ha}\right)$ amounted to $76 \%$ of gross GHG abatement ( $11805 \mathrm{~kg} \mathrm{CO}_{2}$ eq/ha) from the use of biomethane from grass production. Net GHG abatement was $2799 \mathrm{~kg}$ $\mathrm{CO}_{2}$ eq/ha/annum, 2.27 million tonnes (MT) $\mathrm{CO}_{2}$ eq would be mitigated if all of the $11.8 \%$ of land classified as marginal for this purpose (lowland, mineral and wet) is used for biomethane production.

\subsubsection{Scenario 2}

GHG emissions from this scenario were somewhat lower compared to scenario 1 primarily due to reduced diesel consumption and lower fugitive emissions, usage of lime and nitrogen fertilizer were assumed 
to be identical between both scenarios. Emissions during the production of grass and its subsequent conversion to biomethane $\left(8659 \mathrm{~kg} \mathrm{CO}_{2} \mathrm{eq} /\right.$ ha) amounted to $84 \%$ of gross GHG abatement (10280 kg CO 2 eq/ha). Net GHG abatement from this scenario was $1620 \mathrm{~kg} \mathrm{CO}_{2} \mathrm{eq} / \mathrm{ha} / \mathrm{annum}$, $1.31 \mathrm{MT} \mathrm{CO}_{2}$ eq would be mitigated under this scenario if all of the $11.8 \%$ of land classified as marginal for this purpose (lowland, mineral and wet) is used for biomethane production.

\section{Discussion}

Perennial rhizomatous grasses naturally colonise marginal land even though such lands can impose severe restrictions on the growth of vegetation $[24,43,44]$. In this study conducted on marginal land, perennial rhizamatous grasses proved more productive than perennial ryegrass, highest yields were obtained from festulolium and tall fescue grasses. Perennial ryegrass is the grass species of choice for most farmers but lacks resilience against extremes of climate whereas tall fescue shows enhanced adaptation to climatic and edaphic extremes because of a well developed root system and efficient capture of water and nutrients [22]. Tall fescue grasses hybridise readily and festulolium is the hybrid perennial grass developed by crossing Festuca pratensis or Festuca arundinacea with Lolium perenne or Lolium multiflorum combining the best properties of the two grass species [22,45]. It has been reported that festulolium cultivars produced yields which were up to $45 \%$ greater than those of perennial ryegrass cultivars in Latvia [46]. Additionally, it has been shown that novel festulolium cultivars can significantly reduce run-off during flooding as a result of intense initial root growth and it has been suggested that grasses of this type show potential for reducing the likelihood of flooding, whilst providing food production under changing climatic conditions [22]. Furthermore, the photosynthetic capacity of festulolium has been found to be significantly greater than that of miscanthus genotypes at cooler temperatures suggesting that festulolium may be more productive than miscanthus in cool, maritime climates [47]. From our study, it is clear that grass production on marginal land can be optimised when the commonly used perennial ryegrass cultivars are replaced with hardy hybrid grasses better adapted to grow under difficult conditions.

Yields from marginal lands are typically lower than yields from higher grade soils [13]. Yields on the best soils can be up to three times greater than yields from marginal soils [48]. In Ireland, marginal soils are typically those with poor drainage and, in some instances, susceptibility to flooding. Ryan [49] showed that dry matter production was reduced by $2 \mathrm{t} /$ ha on poorly drained soils compared to dry soils. It has been suggested [50] that grass yields may be depressed by up to $25 \%$ in poorly drained soils. Yields on a heavy clay soil have been found to be reduced to between $70 \%$ and $83 \%$ of yields on lighter soils, depending on nitrogen level [51]. In our study, yields on the wet site were reduced by $15 \%$ compared to the control site. Thus yields were not reduced to the extent reported by Ref. [51]. The mitigation of yield reduction on wet soils may have been partially attributable to the use in our experiments of a range of resilient perennial rhizamatous grasses as management practises to increase biomass production in wet environments include the use of tolerant genotypes [24]. All sites were fertilized to ensure adequate nutrition. Consequently, the reduction in yield of $15 \%$ on wet soils compared to better soils possibly reflects soil type limitations and/or cooler temperatures on these soils. The difference in yield between wet soils and drier soils will be magnified where poor trafficability makes harvesting difficult or impossible. In such circumstances, the quantity of biomass harvested from marginal land will decrease due the fact that biomass cannot be harvested when it is not possible for machinery to travel on wet land. Alternatively, the biomass yields in subsequent harvests can also be expected to decrease if harvest machinery traffic results in compaction. The avoidance of machinery damage is one of the key management practises for increasing biomass production in wet environments [24]. Even light machinery damage can cause compaction in grassland under wet conditions but the impact of machinery may be reduced by using low tyre pressures [52]. Low pressure tires, lightweight pickup wagons and the use of umbilical systems for digestate spreading represent machinery options which can maximise grass yields from marginal soils by allowing field operations in wet conditions while minimising soil damage.

There is a degree of uncertainty about the definition and characterisation of marginal land which has caused uncertainty in assessments of land availability and of future bioenergy potentials [13]. In this study, we have used a figure of 810,000 ha [20] as our basis for the quantification of marginal land. However, it is difficult to be certain of the exact quantity of marginal land as well as of the exact proportion of such land which may be used for bioenergy production. The use of grassland for biomethane production in any given area will only occur if farmers find the economics sufficiently attractive to either build an anaerobic digestor on their farm or to supply grass to an anaerobic digestor built nearby. The proximity of an anaerobic digestor to a farm will be a critical factor in determining uptake as excessive transport costs will mitigate the economic advantages of supplying grass for biomethane production. Similarly, any additional costs in the preparation or use of the grassland for biomethane production will negate the advantages of producing grass for biomethane production. The marginal land defined by Ref. [20] is most likely used for beef production as $68 \%$ of Irish farms are used for beef production in full or in part [53]. However, the income which most Irish cattle farmers receive does not cover the cost of production [54] making alternative, more profitable, uses of grassland attractive to cattle farmers particularly when there is no change in land use involved which allows the farmer to seamlessly revert to cattle rearing.

Energy use in the transport sector in Ireland was last collated for 2014 [42]. On the basis of this report, the net energy available when lowland, wet, mineral marginal land is used for biomethane production to its full potential (scenario 1) would be able to meet the energy needs of all the private cars in the country in addition to the energy needs of all heavy goods vehicles. The net energy available from scenario 2 would be sufficient to meet the energy needs of all the private cars in the country in addition to the energy needs of all taxis, hackneys and passenger buses. The biggest energy cost was the production of parasitic heat to heat the digestor. Smyth et al. [27] included a scenario in which the combustion of wood chips was used to supply the parasitic heat demand for the digestor. In this scenario, there was only a small decrease in the net energy balance but the volume of biomethane available for transport use increased considerably. It has been calculated [17] that $5.75 \%$ of transport fuel requirements in Ireland could be supplied from biomethane grown on $1.6 \%$ of agricultural land. Also, $10 \%$ of Irish grassland could fuel over $55 \%$ of the Irish private car fleet [27]. However, ambitious targets exist for the Irish dairy and beef sectors which are likely to result in changes in the size and composition of the national herd [55]. It is estimated that only a relatively small proportion of the grassland biomass resource (0.4 MT DM/annum) would be available for alternative uses following the implementation of the targets although this figure could increase to over 12 MT DM/ annum through increased fertilizer nitrogen input and grass utilization [16]. Our study has shown that an alternative strategy in which bioenergy production is focussed on certain categories of marginal land would provide a substantial proportion of the national transport energy requirement. Such a strategy which allows the better land to be used for food production reduces competition between food production and energy production.

Total emissions of greenhouse gases from Ireland in 2015 amounted to almost $59 \mathrm{MT}\left(\mathrm{CO}_{2}\right.$ eq) [37]. A strategy which uses all of the low lying, mineral and wet marginal land for biomethane production would reduce national emissions by almost $4 \%$ if grass production and harvesting was not hampered by wet conditions (scenario 1) but this saving reduced to $2.2 \%$ in scenario 2 . This, relatively small GHG saving, resulted from strategies which provided substantial proportions of national energy needs. A substantial proportion of emissions in the Life 
Cycle Assessment were associated with the production and use of lime and nitrogenous fertilizers. Emissions associated with the production of nitrogen fertilizer were limited because of the relatively small quantity of chemical fertilizer needed after digestate utilization but emissions of $\mathrm{N}_{2} \mathrm{O}$ after the application of both digestate and chemical $\mathrm{N}$ fertilizer were substantial and represented a considerable proportion of GHG emissions. Emissions of $\mathrm{N}_{2} \mathrm{O}$ following fertilizer application were calculated using a default emission factor of $0.01 \mathrm{~kg} \mathrm{~N} 20-\mathrm{N} / \mathrm{ha} / \mathrm{annum}$ [36]. However, higher emission factors have been reported from heavy, wet soils [56]. Higher emissions factors would lead to further increases in the emissions associated with the use of grassland for biomethane production. Nitrogen application rates used in this study $(325 \mathrm{~kg} \mathrm{~N} / \mathrm{ha}$ ) represented the maximum limit of $\mathrm{N}$ application to grassland [25]. High $\mathrm{N}$ application rates were used in order to stimulate grass production and attain maximum site productivity but similar yields may be possible with lower nitrogen application rates which would reduce greenhouse gas emissions associated with fertilizer manufacture and application. Increasing the input of $\mathrm{N}$ can substantially increase grass production from both conventional agricultural land [16] as well as from marginal agricultural land and provide a substantial grass resource for energy production without compromising food production. However, GHG emissions associated with enhanced fertilizer use represent a substantial proportion of the emissions associated with biomethane production from grassland. Thus, bioenergy strategies which include the reduction of GHG emission as an objective need to carefully consider the implications of enhanced fertilizer application. The use of diverse swards which include perennial legumes should reduce the quantity of nitrogenous fertilizers needs to maintain sward productivity and consequently reduce GHG emissions from grass based biomethane production [57].

\section{Conclusions}

Marginal grassland in lowland areas on mineral soils in Ireland can be almost as productive as conventional agricultural land particularly if resilient perennial rhizomatous grasses such as festulolium are used for grass production. Marginal grasslands in Ireland are currently underutilised but strategies which maximise yields from such grasslands and use the grass for biomethane production could produce a substantial proportion of national transport energy requirements without compromising national targets for agricultural production.

\section{Acknowedgements}

This work was part of the Grassmargins project which was funded by the European Union's Seventh Framework Programme (grant agreement KBBE-2011-5-289461). The authors gratefully acknowledge the assistance of Dr Jim Grant, Peter Gaskin, Rioch Fox and Nicholas Hayes.

\section{References}

[1] G. Fischer, L. Schrattenholzer, Global bioenergy potentials through 2050, Biomass Bioenerg. 20 (3) (2001) 151-159.

[2] G. Berndes, M. Hoogwijk, M.R. van den Broek, The contribution of biomass in the future global energy supply: a review of 17 studies, Biomass Bioener 25 (1) (2003) $1-28$.

[3] R. Offermann, T. Seidenberger, D. Thrän, M. Kaltschmitt, S. Zinoviev, S. Miertus, Assessment of global bioenergy potentials, Mitig. Adapt. Strategies Glob. Change 16 (1) (2011) 103-115.

[4] G. Marland, M. Obersteiner, Large-scale biomass for energy, with considerations and cautions: an editorial comment, Clim. Change 87 (3-4) (2008) 335-342.

[5] K. Cassman, A.J. Liska, Food and fuel for all: realistic or foolish? Biofuel Bioprod, Bior 1 (1) (2007) 18-23.

[6] R. Slade, A. Bauen, R. Gross, Global bioenergy resources, Nat. Clim. Change 4 (2) (2014) 99-105.

[7] H. Lotze-Campen, A. Popp, T. Beringer, C. Müller, A. Bondeau, S. Rost, W. Lucht, Scenarios of global bioenergy production: the trade-offs between agricultural expansion, intensification and trade, Ecol. Model 221 (18) (2010) 2188-2196.

[8] J.E. Campbell, D.B. Lobell, R.C. Genova, C.B. Field, The global potential of bioenergy on abandoned agriculture lands, Envir. Sci. Tech. 42 (15) (2008) 5791-5794.

[9] C.B. Field, J.E. Campbell, D.B. Lobell, Biomass energy: the scale of the potential resource, Trends Ecol. Evol. 23 (2) (2008) 65-72.

[10] V.H. Dale, K.L. Kline, J. Wiens, J. Fargione, Biofuels: Implications for Land Use and Biodiversity, Ecological Society of America, Washington, DC, USA, 2010 Jan.

[11] S. Fritz, L. See, M. van der Velde, R.A. Nalepa, C. Perger, C. Schill, I. McCallum, D. Schepaschenko, F. Kraxner, X. Cai, X. Zhang, Downgrading recent estimates of land available for biofuel production, Environ. Sci. Technol. 47 (3) (2013) 1688-1694.

[12] M. Hoogwijk, A. Faaij, R. Van Den Broek, G. Berndes, D. Gielen, W. Turkenburg, Exploration of the ranges of the global potential of biomass for energy, Biomass Bioener 25 (2) (2003) 119-133.

[13] J. Dauber, C. Brown, A.L. Fernand, J. Finnan, E. Krasuska, J. Ponitka, D. Styles, D. Thrän, K.J. Van Groenigen, M. Weih, R. Zah, Bioenergy from "surplus" land: environmental and socio-economic implications, BioRisk 7 (2012) 5-50.

[14] D.K. Bryngelsson, K. LindgreN, Why large-scale bioenergy production on marginal land is unfeasible: a conceptual partial equilibrium analysis, Energ. Policy 55 (2013) 454-466.

[15] D. Tilman, J. Hill, C. Lehman, Carbon-negative biofuels from low-input high-diversity grassland biomass, Science 314 (5805) (2006) 1598-1600.

[16] J. McEniry, P. Crosson, E. Finneran, M. McGee, T.W.J. Keady, P. O'Kiely, How much grassland biomass is available in excess of livestock requirements? Irish J. Agr. Food Res. 52 (1) (2013) 67-80.

[17] J.D. Murphy, N.M. Power, An argument for using biomethane generated from grass as a biofuel in Ireland, Biomass Bioener 33 (3) (2009) 504-512.

[18] D.M. Wall, P. O'Kiely, J.D. Murphy, The potential for biomethane from grass and slurry to satisfy renewable energy targets, Bioresour. Technol. 149 (2013) 425-431.

[19] M.J. Gardiner, T. Radford, Soil Associations of Ireland and Their Land Use Potential. in: Soil Survey Bulletin Vol. No. 36, An Foras Talúntais (The Agricultural Institute), 198019 Sandymount Avenue, Dublin 4.

[20] F. O'Mara, Country Pasture/forage Resource Profile Ireland, FAO/Teagasc, (2008) http://www.fao.org/ag/agp/agpc/doc/Counprof/Ireland/Ireland.htm , Accessed date: 4 January 2017.

[21] L. Shalloo, P. Creighton, M. O'Donovan, The economics of reseeding on a dairy farm, Irish J Agric, Food Res. 50 (2011) 113-122.

[22] C. Macleod, M.W. Humphreys, M.R. Whalley, L. Turner, A. Binley, C.W. Watts, L. Skot, A. Joynes, S. Hawkins, I.P. King, S. O' Donovan, P.M. Haygarth, A novel grass hybrid to reduce flood generation in temperate regions, Sci. Rep. 3 (1683) (2013), http://dx.doi.org/10.1038/srep01683.

[23] X.G. Zhu, T.G. Chang, Q.F. Song, J. Finnan, S. Barth, L.M. Mårtensson, M.B. Jones, A Systems Approach Guiding Future Biomass Crop Development on Marginal Land, in Perennial Biomass Crops for a Resource-constrained World, Pp. 209-224, Springer International Publishing, 2016.

[24] M.B. Jones, J. Finnan, T.R. Hodkinson, Morphological and physiological traits for higher biomass production in perennial rhizomatous grasses grown on marginal land, Glob. Change Biol. Bioener 7 (2) (2015) 375-385.

[25] B.S. Coulter, S. Lalor, Major and Micro Nutrient Advice for Productive Agricultural Crops, ISBN No 184170 5012, third ed., (2008) Available at: www.agresearch. teagasc.ie/johnstown/publications.asp , Accessed date: 15 December 2011.

[26] SAS Version 9.3, SAS Institute Inc., Cary, NC, USA, 2009.

[27] B.M. Smyth, J.D. Murphy, C.M. O'Brien, What is the energy balance of grass biomethane in Ireland and other temperate northern European climates? Renew. Sustain. Energy Rev. 13 (2009) 2349-2360.

[28] EC Directive 2009/28/EC of the European Parliament and of the Council of 23 April 2009 on the promotion of the use of energy from renewable sources and amending and subsequently repealing Directives 2001/77/EC and 2003/30/EC. OJEU: L $140 / 16$.

[29] A. Prochnow, M. Heiermann, M. Plöchl, B. Linke, C. Idler, T. Amon, P.J. Hobbs, Bioenergy from permanent grassland - a review: 1. Biogas, Bioresour. Technol. 100 (21) (2009) 4931-4944.

[30] M. Seppälä, T. Paavola, A. Lehtomäki, J. Rintala, Biogas production from boreal herbaceous grasses - specific methane yield and methane yield per hectare, Bioresour. Technol. 100 (12) (2009) 2952-2958.

[31] J. McEniry, P. O'Kiely, Anaerobic methane production from five common grassland species at sequential stages of maturity, Bioresour. Technol. 127 (2013) 143-150.

[32] V.Z. Tilvikiene, Z. Kadziuliene, K. Dabkevicius, K. Venslauskas, K. Navickas, Feasibility of tall fescue, cocksfoot and reed canary grass for anaerobic digestion: analysis of productivity and energy potential, Ind. Crops Prod. 84 (2016) 87-96.

[33] T. Dalgaard, N. Halberg, J.R. Porter, A model for fossil energy use in Danish agriculture used to compare organic and conventional farming, Agr. Ecosyst. Environ. 87 (1) (2001) 51-65.

[34] M. Kelm, M. Wachendorf, H. Trott, K. Volkers, F. Taube, Performance and environmental effects of forage production on sandy soils. III. Energy efficiency in forage production from grassland and maize for silage, Grass Forage Sci. 59 (1) (2004) 69-79.

[35] D. Styles, M.B. Jones, Energy crops in Ireland: quantifying the potential life-cycle greenhouse gas reductions of energy-crop electricity, Biomass Bioener 31 (11) (2007) 759-772.

[36] C. De Klein, R. Novoa, S. Ogle, K. Smith, P. Rochette, T. Wirth, B. McConkey, A. Mosier, K. Rypdal, M. Walsh, S.A. Williams, N2O emissions from managed soils, and $\mathrm{CO} 2$ emissions from lime and urea application, in: S. Eggleston, L. Buendia, K. Miwa, T. Ngara, K. Tanabe (Eds.), IPCC Guidelines for National Greenhouse Gas Inventories, Published by the Institute for Global Environmental Strategies, Hayama, Kanagawa, Japan, 2006, pp. 11.1-11.54.

[37] P. Duffy, E. Hanley, K. Black, P. O Brien, B. Hyde, J. Ponzi, S. Alam, Ireland National 
Inventory Report 2015. Greenhouse Gas Emissions 1990-2013 Reported to the United Nations Framework Convention on Climate Change. Environ. Prot. Agency, PO Box 3000, Johnstown Castle, Wexford, Ireland. http://coe.epa.ie/ghg/data/ inventories/2015/IE 2015 NIR2.pdf. Accessed 19/12/2016.

[38] B. Dieterich, J. Finnan, T. Hochstrasser, C. Müller, The greenhouse gas balance of a dairy farm as influenced by the uptake of biogas production, Bioenergy Res. 7 (1) (2014) 95-109.

[39] EC, Well to Wheels Analysis of Future Automotive Fuels and Powertrains in the European Context. European Commission, Concawe and Eucar (European Council for Automotive R \& D), (2006).

[40] H. Flessa, R. Ruser, P. Dörsch, T. Kamp, M.A. Jimenez, J.C. Munch, F. Beese, Integrated evaluation of greenhouse gas emissions ( $\mathrm{CO} 2, \mathrm{CH} 4, \mathrm{~N} 2 \mathrm{O}$ ) from two farming systems in southern Germany, Agr. Ecosyst. Environ. 91 (1) (2002) 175-189.

[41] M. Howley, M. Holland, D. Dineen, E. Cotter, Energy in Ireland 1990-2014. Sustainable Energy Authority of Ireland, (2015) http://www.seai.ie/Publications/ Statistics_Publications/Energy_in_Ireland/Energy-in-Ireland-1990-2014.pdf Accessed date: 19 December 2016.

[42] D. Dineen, M. Howley, M. Holland, Energy in transport. Sustainable energy authority of Ireland, Accessed 19/12/2016" > https://www.seai.ie/Publications/ Statistics_Publications/Energy_in_Transport/Energy-in-Transport-2014-report.pdf (2014) , Accessed date: 19 December 2016.

[43] M.D. Casler, Switchgrass breeding, genetics, and genomics, in: A. Monti (Ed.), Switchgrass, a Valuable Biomass Crop for Energy, Springer-Verlag, London, 2012, pp. 29-53.

[44] J. Clifton-Brown, Y.C. Chiang, T.R. Hodkinson, T.R. Miscanthus, Genetic resources and Breeding potential to enhance bioenergy production, in: W. Vermerris (Ed.), Genetic Improvement of Bioenergy Crops, Springer, New York, 2008, pp. 295-308.

[45] S. Rancane, A. Karklins, D. Lazdina, P. Berzins, A. Bardule, A. Butlers, A. Lazdins, The evaluation of biomass yield and quality of Phalaris arundinacea and Festulolium fertilised with bio-energy waste products, Agron. Res. 14 (1) (2016) $198-210$.

[46] I. Gutmane, A. Adamovich, Productivity aspects of Festulolium and Lolium x boucheanum cultivars, Grassl. Sci. Eur. 11 (2006) 155-157.

[47] J. Xiurong, K. Kørup, M.A. Andersen, E.J. Sacks, X.G. Zhu, P.E. Lærke, U. Jørgensen,
Can miscanthus C4 photosynthesis compete with festulolium C3 photosynthesis in a temperate climate, Glob. Change Biol. Bioenerg. (2016), http://dx.doi.org/10. $1111 /$ gcbb 12342 .

[48] G. Fischer, S. Prieler, H. van Velthuizen, M. Sander, M. Lensink, Marc Londo, M. de Wit, Biofuel production potentials in Europe: sustainable use of cultivated land and pastures. Part I: land productivity potentials, Biomass Bioener 34 (2) (2010) 159-172.

[49] M. Ryan, Grassland productivity: 1. Nitrogen and soil effects on yield of herbage, Ir. J. Agr. Res. 13 (3) (1974) 275-291.

[50] A.J. Thomasson, The Effect of Drainage Conditions on Grassland Production. Water Control and Grassland Productivity. in: Proceedings of the British Grassland Society Winter Meeting, British Grassland Society, Hurley, UK, Dec. 19791.1-1.11.

[51] L. Shalloo, P. Dillon, J. O'loughlin, M. Rath, M. Wallace, Comparison of a pasturebased system of milk production on a high rainfall, heavy-clay soil with that on a lower rainfall, free-draining soil, Grass Forage Sci. 59 (2) (2004) 157-168.

[52] D. Forristal, O. Fenton, R. Cramer, Compaction-prevention better than cure. Todays Farm 24, 25-28, Available at: http://www.teagasc.ie/publications/2013/1843/ TodaysFarm_JanFeb2013.pdf. Accessed 20/12/2016.

[53] CSO, Census of Agriculture, (2010) Accessed 20/12/2016" > http://www.cso.ie/ en/media/csoie/releasespublications/documents/agriculture/2010/full2010.pdf , Accessed date: 20 December 2016.

[54] T. Donnelan, K. Hanrahan, F. Thorne, J. Casey, M. McKeon, A. Kinsella, A. B. Moran, Outlook 2017. Economic Prospects for Agriculture. https://www.teagasc. ie/media/website/publications/2016/Outlook2017web.pdf. Accessed 12/12/ 2016.

[55] DAFF (Department of Agriculture, Fisheries and Food), Food Harvest 2020-A Vision for Irish Agri-food and Fisheries, (2010) Available online https://www.agriculture. gov.ie/media/migration/foodindustrydevelopmenttrademarkets/agrifoodandtheeconomy/foodharvest2020/2020FoodHarvestEng240810.pdf , Accessed date: 15 December 2016.

[56] R. Rafique, D. Hennessy, G. Kiely, Nitrous oxide emission from grazed grassland under different management systems, Ecosystems 14 (4) (2011) 563-582.

[57] G. Carlsson, L.M. Mårtensson, T. Prade, S.E. Svensson, E.S. Jensen, Perennial species mixtures for multifunctional production of biomass on marginal land, Glob. Change Biol. Bioeneg 9 (1) (2017) 191-201. 